\title{
Piloting a method to evaluate the implementation of integrated water resource management in the Inkomati River Basin
}

\author{
Melanie J Wilkinson', Thandi K Magagula1* and Rashid M Hassan² \\ 'Prime Africa Consultants, 53 Woodpecker Avenue, Newlands, Pretoria 0181, South Africa, 0181 \\ ${ }^{2}$ Centre for Environmental Economics and Policy in Africa, University of Pretoria, South Africa
}

\begin{abstract}
This paper provides an assessment of the implementation of principles of integrated water resource management (IWRM) in the Inkomati River Basin (IRB), shared by South Africa, Swaziland and Mozambique. A methodology with a set of principles, change areas and measures was developed as a performance assessment tool. The tool was piloted in the IRB and results from the application were used to refine and finalise the tool. Piloting of the tool did provide very useful insights into IWRM implementation in the IRB and highlighted gaps where future attention needs to focus. Good progress has been realised with respect to creating the enabling environment and institutional frameworks as the key principles of IWRM have been successfully articulated in policy and legislation and a relatively satisfactory degree of stakeholder participation achieved. Measures related to the IWRM implementation instruments seem to be the least developed, particularly the financial enabling environment and institutional capacity building change areas. More attention also needs to be paid to conflict resolution mechanisms. The results from the pilot also showed that countries should consider a phased approach to assessment of IWRM, as implementation does seem to follow a process of creating the enabling environment, followed by formulating and implementing the institutional framework and creation and application of IWRM management instruments.

Keywords: Integrated water resource management, Inkomati River Basin, South Africa, Swaziland
\end{abstract}

\section{INTRODUCTION}

Agenda 21, a non-binding, voluntarily implemented action plan for sustainable development which emanated out of the 1992 United Nation's Conference on Environment and Development (UNCED), indicates in Chapter 18 that there is a need for 'the application of integrated approaches to the development, management and use of water resources' (UNCED, 1992 p. 196).

Despite the UNCED advocating integrated management of water resources, the concept remained ambiguous and imprecisely defined until the 2002 World Summit on Sustainable Development (WSSD) where the Technical Advisory Committee of the Global Water Partnership (GWP) defined integrated water resources management (IWRM) as a process which promotes the co-ordinated development and management of water, land and related resources in order to maximise the resultant economic and social welfare in an equitable manner without compromising the sustainability of vital ecosystems (GWP, 2000 p. 22). The Technical Advisory Committee of GWP also emphasize that water should be managed in a basinwide context, under the principles of good governance and public participation (GWP, 2000).

Acknowledging that there is no universal blueprint for IWRM, the GWP recognised that there are certain basic IWRM principles which can be commonly applied in most economic and social contexts, including economic efficiency, equity and sustainability in water use. The GWP recommended framework and approach to implementing IWRM includes complementary pillars within the basic IWRM principles, each of which must be developed and strengthened concurrently (GWP, 2000). These complementary pillars include:

* To whom all correspondence should be addressed.

Email: t.magagula@primeafrica.net

Received: 15 July 2014; accepted in revised form 25 August 2015
- The enabling environment - with IWRM being the foundation of national policies, legislation and regulations

- The institutional roles and functions - where the roles and functions of the various administrative levels and stakeholders are designed and outlined to address IWRM principles

- The management instruments - where IWRM underpins operational instruments for effective regulation, monitoring and enforcement and thus allows decision-makers to make informed choices

It is within this framework that many Southern African countries embarked on water reforms in the early 1990s (Van der Zaag, 2005; GWP, 2000). The premise at the time was that if the institutional structure (laws, regulations, organisations) for the implementation of IWRM was in place, this process would evolve in the country and water management would be strengthened and become a participatory, stakeholder-driven process.

After more than a decade of IWRM implementation, this paper provides the results of piloting of a method to assess the implementation of IWRM principles by in-country river basin management institutions in the Inkomati River Basin (IRB), shared between South Africa, Swaziland and Mozambique. The methodology, with a set of principles, change areas and measures was developed as a performance assessment tool and piloted in the IRB. Lessons learnt from the application and pilot testing of the performance assessment tool are used to refine and finalise the tool to be used for similar future assessments.

\section{The case study description: Inkomati River Basin (IRB)}

The IRB was chosen as a study area for this assessment as three states, each at a different stage of IWRM implementation, are involved in management of the common water resource in the basin. This allowed useful comparative analysis of their experiences in applying IWRM principles. 
The IRB is one of 15 international river basins in the Southern African Development Community (SADC). It covers approximately $47000 \mathrm{~km}^{2}$ and extends from the eastern part of South Africa, through the north of Swaziland and into the southern part of Mozambique, where it discharges into the Indian Ocean (Fig. 1). The IRB comprises $28700 \mathrm{~km}^{2}(61 \%)$ in South Africa; $15500 \mathrm{~km}^{2}$ (31\%) in Mozambique and $2600 \mathrm{~km}^{2}$ (6\%) in Swaziland (Carmo Vaz and Pereira, 2000). It is estimated that 2 million people live in the river basin with the main economic activities being irrigated agriculture, afforestation, mining and tourism.

The use of water in the Basin is guided by the 2002 Tripartite Interim Agreement on Water Sharing (TIAWS) of the Maputo and Incomati Rivers (the IncoMaputo agreement), which is based on a principle of equitable use as explained in Article 7(1) of the agreement, namely that 'the three countries (parties) shall be entitled, in their respective territories, to optimal and sustainable utilisation of and benefits from the water resources of the Incomati and Maputo, taking into account the interest of the other parties concerned, consistent with the adequate protection of the water courses for the benefit of the present and future generations' (Van der Zaag and Carmo Vaz, 2003).

\section{METHODS}

A hierarchical approach was utilised to conduct the IWRM performance assessment. The hierarchical approach allowed structuring of data and results in a useful analytical framework. The hierarchy comprises the three principles and three pillars of IWRM, as outlined by the GWP (see Fig. 2).

Within these pillars are the 13 change areas used to assess performance in the IRB:
- Under the enabling environment

- Policies - setting goals for water use, protection and conservation

- Legislative framework - the rules to follow to achieve policies and goals

- Financing and incentive structures - allocating financial resources to meet water needs

- Under institutional roles

- Creating an organisational framework - forms and functions

- Stakeholder participation

- Institutional capacity building - developing human resources

- Under management instruments

- Water resources assessment - understanding resources and needs

- Plans for IWRM - combining development options, resource use and human interaction

- Demand management - using water more efficiently

- Conflict resolution - managing disputes, ensuring sharing of water

- Regulatory instruments - allocation and water use limits

- Economic instruments - using value and prices for efficiency and equity

- Information management and exchange - improving knowledge for better water management

The hierarchy assumes that each level in the structure would provide data and inform the level above (i.e. measures provide details on the performance in the change area, while information from all the relevant change areas would allow conclusions to be drawn for the performance in the related IWRM pillar).

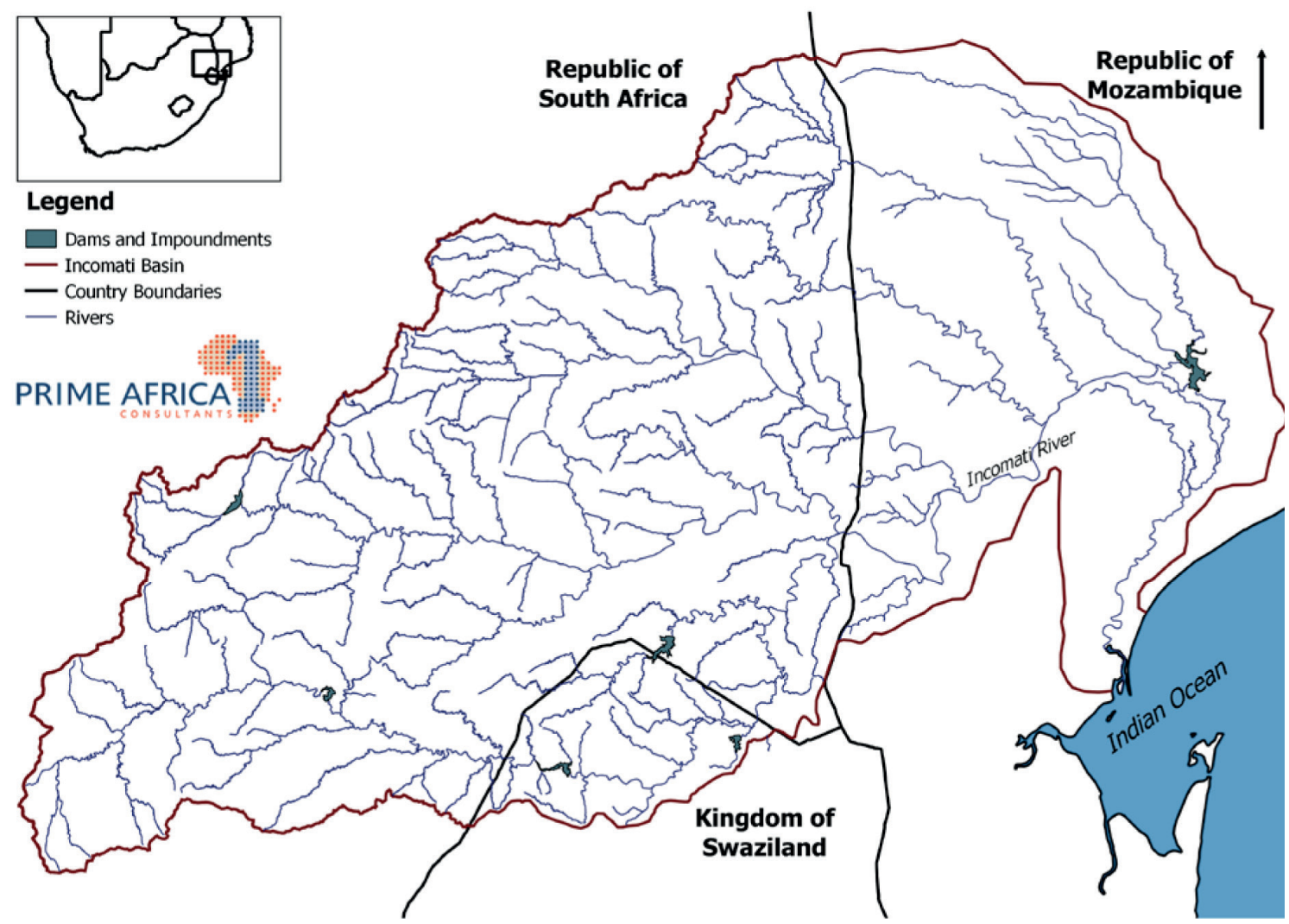

Figure 1

Map of the Inkomati River Basin 
Data was collected from both primary and secondary sources. Primary data was collected through a questionnaire that targeted stakeholders with a background and knowledge of the process of water management in the IRB. The questionnaires comprised a series of structured questions (measures) which relate to one or more of the 13 IWRM change areas under assessment (Hassan et al., 2014).

The sampling methodology employed to select survey participants was non-random (purposive), with respondents purposefully selected to address the objective which determines the effectiveness of implementation of the IWRM change areas in specific institutions (Prinsloo, 2008). The study initially aimed to assess the implementation of principles of IWRM in Mozambique, South Africa and Swaziland. However, conducting surveys within Mozambique was a challenge, with a very limited number of responses to the survey. Mozambique's IWMR results were therefore not included in this paper. Table 1 below shows the number of respondents in South Africa and Swaziland (i.e. targeted participants versus participants who actual responded to the survey).

The results for 17 respondents: South Africa (11) and Swaziland (6) were included in this piloting of the IWRM assessment method, emanating from public organisations, water management institutions and commercial users. It should be noted that the very limited number of organisations included in the assessment was driven by the criteria for selecting participating organisations. For example, organisations had to be directly involved in water management or water use in the IRB. In the case of Swaziland, the six respondents who were included in the study were shown to be the most important stakeholders who should be included in the study. The respondents indicated that interviewing additional respondents, other than these six, would not provide any additional useful information.

Survey data were captured and coded into an Excel database and then imported into the Statistical Package for Social Sciences (SPSS) software for analysis. In the interpretation of results, the term 'respondents' refers to 'respondents who answered the question' and blank data points in the database were not included in the reported analysis of results.

\section{RESULTS AND DISCUSSION}

This section presents and discusses results of the performance assessment in South Africa and Swaziland based on the above described analytical framework (Fig. 2).

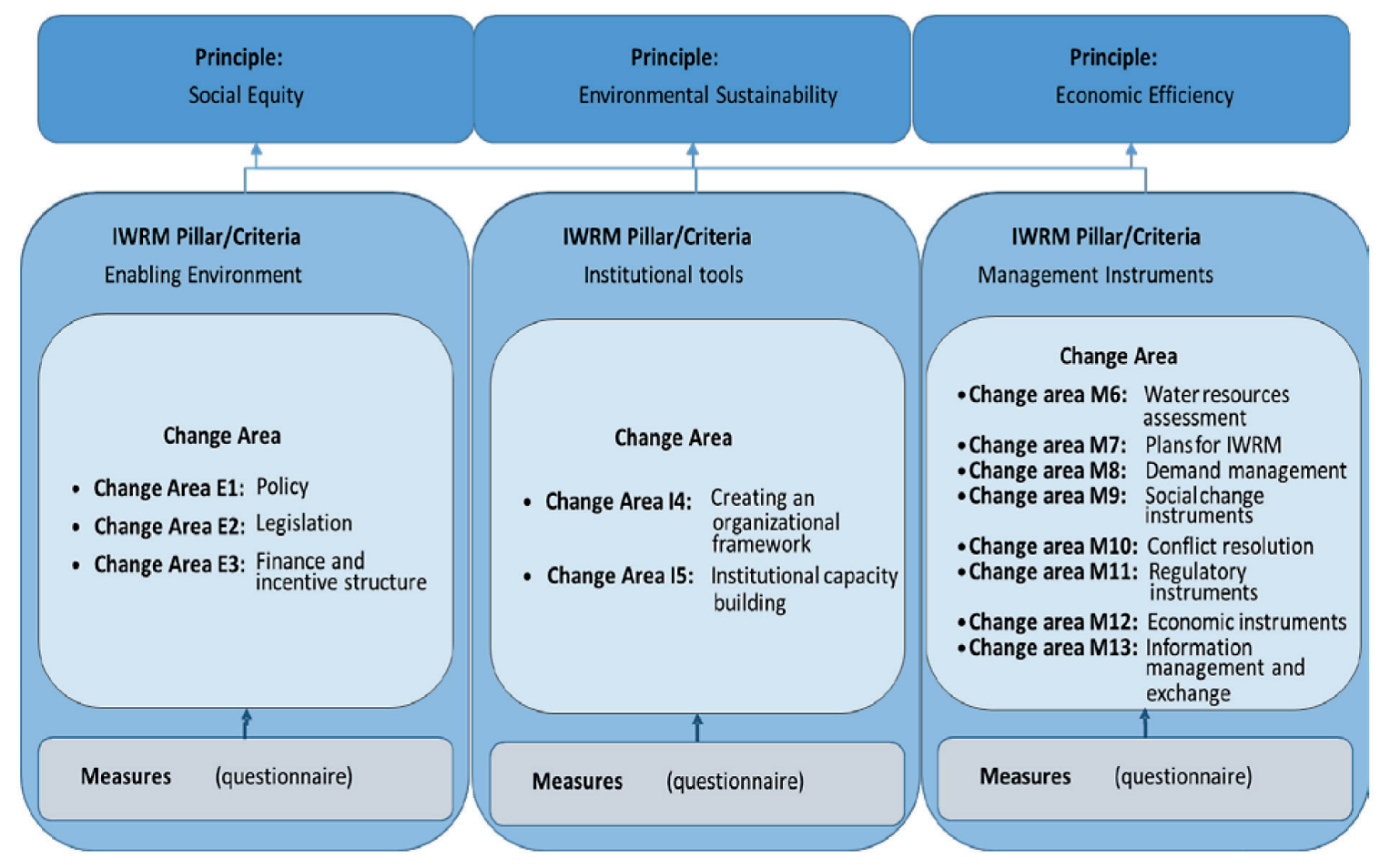

Figure 2

Hierarchy approach utilised in the performance assessment of IWRM in the Inkomati River Basin (adapted from GWP, 2000)

\begin{tabular}{|c|c|c|c|c|c|c|}
\hline \multicolumn{7}{|c|}{$\begin{array}{cc}\text { TABLE } 1 \\
\text { Number of respondents targeted and positive response }\end{array}$} \\
\hline \multirow{3}{*}{ Organisation categories } & \multicolumn{4}{|c|}{ Country } & \multicolumn{2}{|c|}{ Total } \\
\hline & \multicolumn{2}{|c|}{ South Africa } & \multicolumn{2}{|c|}{ Swaziland } & \multirow[b]{2}{*}{ Targeted } & \multirow[b]{2}{*}{ Participated } \\
\hline & Targeted & Participated & Targeted & Participated & & \\
\hline Water resource management institutions & 8 & 4 & 2 & 2 & 10 & 6 \\
\hline Commercial users & 8 & 4 & 4 & 3 & 12 & 7 \\
\hline Emerging users & 2 & $\mathbf{0}$ & 2 & 1 & 4 & 1 \\
\hline Environmental interest groups & 4 & 3 & 1 & $\mathbf{0}$ & 5 & 3 \\
\hline Total & 22 & 11 & 9 & 6 & 31 & 17 \\
\hline
\end{tabular}


According to respondents who participated in survey, progress with implementation of IWRM has been slow in South Africa and Swaziland. In South Africa, for example, the Inkomati is one of only two catchments in the country which has a gazetted catchment management agency (CMA), since the promulgation of the National Water Act. In Swaziland, the establishment of the National Water Authority is still a work in progress, the functions of which are temporarily performed by the Ministry of Natural Resources and Energy, with the Water Affairs Department providing a secretarial and administrative support function.

\section{IWRM enabling environment}

A well-structured and effective IWRM enabling environment is required to facilitate the implementation of water resource management (GWP, 2000). This enabling environment is fostered through developing and implementing policy, legitimising policy in the legal frameworks and planning and coordinating IWRM. In this regard, the experiences and performances of South Africa and Swaziland are evaluated below.

\section{Water policies}

Adopting an integrated approach to water management requires far-reaching reforms of the national and local water policies of a country, followed by legislative reform (UNEP, 2012). South Africa and Swaziland have recently seen changes to their national water policy, with the inclusion of IWRM principles into these primary national water policies.

For example, the South African Government embarked upon a water reform process in 1994 which culminated in a number of new water policies, including the White Paper on Water Supply and Sanitation (1994) and the White Paper on a National Water Policy for South Africa (1997) (RSA, 1994; 1997). Both of these policies remain the leading policy documents in the water services and water resource management sectors of the country. It is clear that South Africa was in a fortunate position as it was able to formulate policy and legislation based upon the experiences of others and to encapsulate the principles of IWRM (Schreiner and Hassan, 2011).

The reform of the Swaziland water policy began with the development of the National Water Policy (NWP) in 2000. In 2006, the Regional Water Policy and Strategy document was approved, followed by the final draft of the NWP which was approved in 2009. The NWP aimed to provide a clear demarcation of responsibilities of various stakeholders and institutions involved in the integrated development and management of water resources in Swaziland (Ministry of Natural Resources \& Energy, National Water Authority, 2009).

Respondents in the IRB case study were asked whether they were aware of water policies in the basin related to allocation, monitoring, pollution and flood/drought control. Table 2 shows that a high number of respondents indicated that they are aware of water policies in place in the IRB, highest among these was awareness of water allocation policies (76\%), followed by awareness of water monitoring policies (71\%). Respondents from South Africa, who demonstrated a high awareness of water monitoring policies in the IRB, indicated that the Inkomati Catchment Management Agency (CMA) is currently actively participating in water monitoring programmes for the catchment.

Less than half (45\%) of the South African respondents indicated awareness of a flood/drought control policy being in place in the basin. More of the Swaziland respondents, on the other hand (67\%), indicated awareness of a flood and drought control policy, outlining that this policy is included in the Water Act of 2003 and forms part of the draft IWRM plan being developed by the Department of Water Affairs of this country.

When respondents were further asked if the current policies contain IWRM principles, South African and Swaziland respondents indicated that current policies do contain IWRM principles.

\section{Legislative framework}

The legislative framework of a country provides the foundations for implementation of IWRM, providing the rules to follow to achieve IWRM policies' imperatives and goals (GWP, 2004). Both South Africa and Swaziland have legislation establishing rights to water, defining organisational structures and mandates, and assigning responsibilities among various institutions managing water resources.

In South Africa, water rights have been established by the new National Water Act (NWA) of 1998 (RSA, 1998), providing the legislative framework for water resource management in the country based on the principles of efficiency, equity and sustainability. The NWA names the Minister of Water Affairs as the custodian of the water resources of the country, with water forming part of a public trust. The Act makes provisions for a suite of water uses, some of which require water authorisation in the form of licensing.

The Department of Water and Sanitation (DWS, formerly the Department of Water Affairs) is the regulator of water in South Africa and has the responsibility to develop and enforce IWRM policy. This includes development and enforcement of water resources and water services policies, legislation, strategies and regulations. The NWA based on the IWRM principle, calls for the establishment of catchment management agencies (CMAs) to take responsibility for water resource management at a regional or catchment level. The role of CMAs is to ensure that water resources are protected, used, developed, conserved, managed and controlled in accordance with national policies, guidelines and standards, through the active participation of local communities and other stakeholders (RSA, 2013). The

\begin{tabular}{|l|c|c|c|}
\hline \multicolumn{3}{|c|}{ TABLE $\mathbf{2}$} \\
\hline \multirow{2}{*}{ Percentage of respondents, per country, who indicated that IWRM policies are in place in the Inkomati River Basin } \\
\cline { 2 - 4 } & \multicolumn{2}{|c|}{ Country $(\boldsymbol{N}=\mathbf{1 7})$} & Total (\%) \\
\hline Water allocation & South Africa $\boldsymbol{n = 1 1}(\%)$ & Swaziland $\boldsymbol{n}=\mathbf{6}(\%)$ & $13(76)$ \\
\hline Water monitoring & $8(73)$ & $5(83)$ & $12(71)$ \\
\hline Water pollution & $10(91)$ & $2(33)$ & $10(59)$ \\
\hline Flood and drought control & $7(64)$ & $3(50)$ & $9(53)$ \\
\hline
\end{tabular}


NWA also introduces, as part of the IWRM process, the establishment of water user associations (WUAs) to perform operational functions in support of localised water management.

In addition to the NWA mandate giving responsibility for localised management of water resources to CMAs and WUAs in South Africa, the Water Services Act mandates decentralisation of responsibility for management of water services to water service authorities (WSAs) and water service providers (WSPs) (RSA, 2007). WSAs are metropolitan municipalities, an authorised district municipality or an authorised local municipality which is responsible for ensuring provision of water services within their area of jurisdiction. A WSP, on the other hand, is an organisation or any person who has a contract with a water services authority or another water services provider to sell water to, and/or accept wastewater for the purposes of treatment from, that authority or provider (bulk water services provider); and/or has a contract with a water services authority to assume operational responsibility for providing water services to one or more consumers (end users) within a specific geographic area (retail water services provider).

The decentralisation of water services in South Africa has fared much better than those of water resource management, in that many of the municipalities have embraced their role as local water management institutions and have made significant progress in management of water services at this level. This decentralisation process has not been without its own difficulties. Integration of the role of WSA/WSPs and localised water resource management and institutions has also been slow, largely due to the slow progress in formalising of the decentralised water resource management institutions.

Swaziland enacted its new Water Act in 2003, replacing the Water Act of 1967 (Zaikowski, 2007) to establish a new system of water rights. The new Water Act further declared all water found naturally in the country as a national resource (Zaikowski, 2007) and makes it a requirement for anyone utilising the water to apply for a permit, except for persons or communities who use the water for primary purposes. The institution in Swaziland responsible for regulation of the new Water Act is the Department of Water Affairs (Swaziland Government, 2003).

The new Swaziland Water Act legislates the establishment of:

i) A national water authority (NWA): envisaged to be a highly participatory body corporate whose role is to supervise the activities of the Basin level structures and to provide policy advice to the DWA.

ii) River basin authorities (RBAs): mandated to manage dams and rivers based on resources by issuing water user permits, amongst other responsibilities. There are currently five RBAs in Swaziland, including Lomati, Komati, Mbuluzi, Usuthu and Ngwavuma.

iii) Irrigation districts (IDs): are gazetted body corporates of a two-thirds majority of water users in a district that are mandated by the Act to control the operation and maintenance of works in the district and the distribution of permitted volumes of water in accordance with permits. The ID can also perform functions at the conveyance of the Minister. The ID is governed by a board of directors.

iv) Water user associations (WUAs): At the approval of the ID board a WUA of holders of permits in an area or watercourse/river system can be formed. The objective of the WUA is to maximise the benefits from their permitted water and promote efficient use thereof.

Since 2003, Swaziland has adopted a more decentralised designation of powers to guide the future of water development and management in the country, apart from the Act outlining the establishment of decentralised management institutions.

It is clear that legislation in South Africa and Swaziland mandates the responsibilities of water management authority to RBOs (i.e. catchment management agencies (CMAs) in South Africa and regional basin authorities (RBAs) in Swaziland).

The Inkomati River Basin survey respondents were asked to determine whether the legislation mandates RBOs the responsibility to perform six key management functions, namely: flood/drought control, WRM planning, pollution control, water monitoring, stakeholder participation and water allocation.

The respondents from South Africa were relatively certain that the $\mathrm{RBO}$ has the mandated function of water resource planning and water monitoring (91\%); pollution control (90\%); flood and drought control (86\%) and stakeholder participation (80\%). Relatively fewer respondents indicated the RBO had a legislative mandate for the water allocation function in the basin. This is not surprising as currently RBOs do not have a mandated role in water allocation, as this remains the responsibility of the central government. However, the legislation does grant the Minister the power to devolve responsibility of any of the functions to a RBO.

The Swaziland respondents all attributed the RBA with legislative responsibility for the six functions under review. Respondents also indicated that the legislation provided the Minister with the power to delegate these six functions to the RBA.

\section{Financing and incentive structures}

Countries require funds to be available for basin management to operate in a sustainable manner, necessitating smart financing approaches and appropriate incentives to achieve IWRM goals (GWP, 2004; GWP and INBO, 2009). It is only once these funds have been identified and made available that basin management structures can fulfil their purpose. Most RBOs have limited financial autonomy and depend heavily on allocations from central government budgets, as is the case in South Africa.

Currently South Africa has the only two operational RBOs in the Inkomati Basin, which are funded entirely through taxes collected by the national fiscus. In future, however, RBOs are expected to balance this funding from central government with funds from the collection of water tariffs/charges in the river basin.

The vision for the Swaziland RBOs is for them to be selfsustaining entities (Manyatsi and Brown, 2009). The Water Act mandates a RBO to develop its own water pricing structure and stipulates that it can levy and collect charges to defray part or all costs of the river basin authority.

From a charge/revenue generation perspective, respondents in the Inkomati Basin survey were asked whether RBOs collected user charges/revenue. The majority of South African and Swaziland respondents, $73 \%$ and $83 \%$ respectively, believed that water user tariffs/charges were not collected by the RBO. Only a small group of respondents from South Africa and Swaziland indicated that the user charges/revenues were collected monthly and annually by RBOs and believed that the destination of the funds was the national government.

\section{IWRM institutional roles}

The development and structuring of the most appropriate institution for management of water in a river basin is crucial for the formulation and implementation of IWRM policies and programmes (GWP, 2004). 


\section{Creating an organisational framework - forms and functions}

According to GWP (2004), creating an organisational framework for implementation of IWRM in a river basin starts with the reform of institutions for better water governance and then requires that practitioners consider the required organisations and institutions, from country to basin level and from regulator to water users. Performance with respect to two change areas of relevance to this is examined below for RBOs in the Inkomati Basin.

Literature indicated that water use in South Africa and Swaziland is regulated by a central water-management body within a particular national government ministry (Slinger et al., 2010). The daily water management activities within the IRB are delegated to water management authorities (i.e. ICMA in South Africa and the Komati River Basin Authority (KRBA) in Swaziland). The case study countries envisage the formation of irrigation districts and water user associations for localised management by authorised users with common water interests. The process of formalising these structures is still slow, although South Africa has seen the enacting of a number of WUAs within and surrounding the IRB.

Respondents in the survey were asked whether they felt institutional arrangements were in place in the IRB to support IWRM. Figures 3 and 4 show percentages of respondents in South Africa and Swaziland, respectively, indicating that institutional arrangements were in place. However, these respondents indicated that the process is moving relatively slowly.

Respondents were further asked how they perceived the process of RBO establishment. Both South African and Swaziland respondents indicated that the process was either a top-down driven or a hybrid top-down-bottom-up process with coordination of national government efforts with local efforts. South African respondents were not in agreement on any of the options, with a third indicating a top-down-bottomup process and another quarter of respondents indicating a bottom-up process. Two-thirds of the Swaziland respondents indicated a top-down-bottom-up process, while the remainder felt the process was top-down.

Despite South African and Swaziland respondents indicating a range of processes for the establishment of the RBO, respondents also indicated that the RBOs were being established largely by the national government instead of stakeholder-created institutions.

Respondents in the IRB survey were also asked whether these RBOs were empowered to perform their functions. The majority (90\%) of South African respondents agreed that RBOs are empowered to perform their functions, compared to only $60 \%$ in Swaziland believing that RBOs are empowered.

In an assessment of the performance of the relevant RBOs in the IRB, Fig. 5 shows that respondents in South Africa and Swaziland think RBOs are performing some or a few of the functions. It should also be noted that these two criteria (some and few) could be interpreted to mean the same thing. Responses on these criteria ranged from 35\% in South Africa to $67 \%$ in Swaziland. Very few South African respondents felt that the RBOs were performing all of their functions.

Despite RBO activities being in the early stages of formalisation in South Africa and Swaziland, respondents indicated that local stakeholder-based water management institutions had been created in the IRB. Examples given of such stakeholder water management institutions included: catchment management forums established to discusses various issues ranging from operations and management, to a trans-boundary forum where stakeholders from both countries are represented (i.e. Komati Joint
Operations Forum), a Crocodile Catchment Forum and equivalent forums in other sub-catchments (i.e. TSB, SAPPI), Elands WUA, Inkomati Irrigation Forum (IIF), and WUAs in South Africa); and Emandla-Ekuphila Water District in Swaziland.

Respondents were further requested to provide their opinion as to the independence/authority of the RBO to perform its water management functions. Very low percentages of respondents in both South Africa and Swaziland felt that the RBO had the autonomy to perform their water resource management functions.

Respondents further indicated that government delays decisions made by the RBO in the IRB. The majority of the South African respondents indicated that the government delays would have a severe impact on the service delivered by RBOs, while in Swaziland only half of respondents indicated severe impacts.

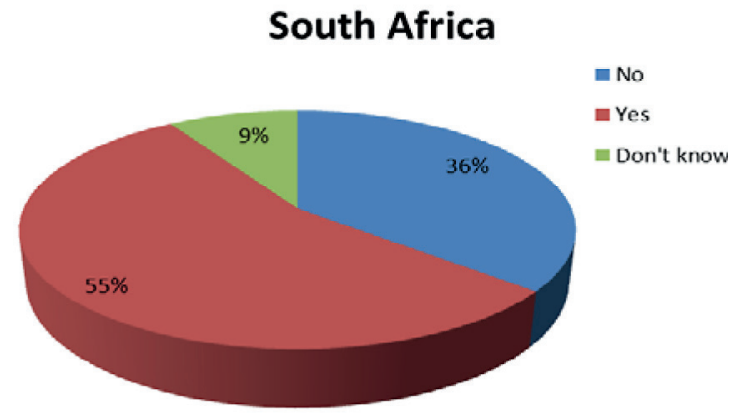

Figure 3

Perception of South African respondents indicating whether institutional arrangements were in place in the Inkomati River Basin to support IWRM

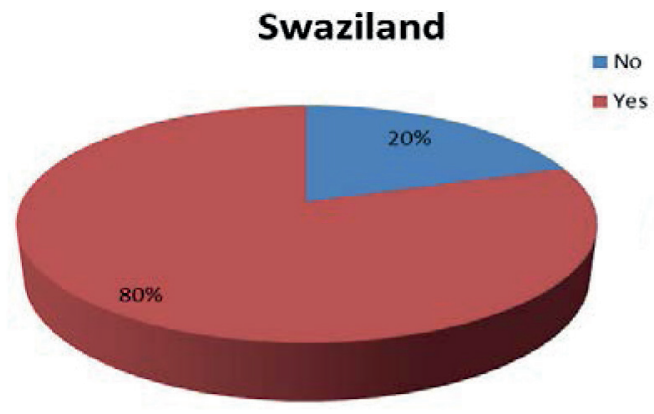

Figure 4

Perception of the Swaziland respondents indicating whether institutional arrangements were in place in the Inkomati River Basin to support IWRM

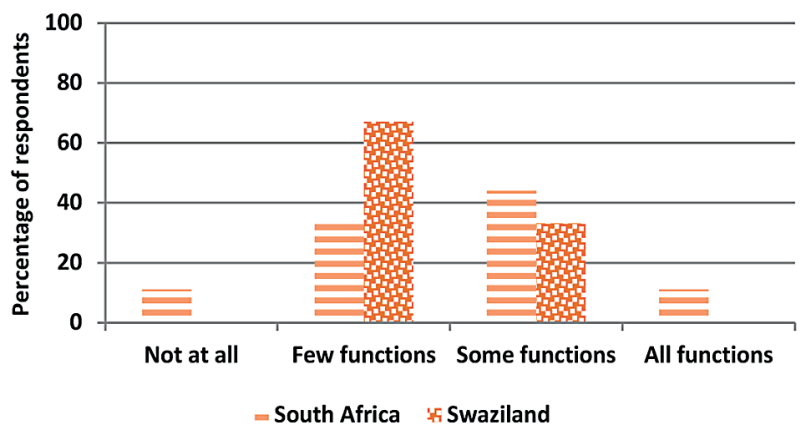

Figure 5

Respondents assessment of performance of the RBOs function in the Inkomati River Basin (South Africa and Swaziland) 


\section{Stakeholder participation}

Stakeholder participation in water management in a basin should include all stakeholders in the horizontal structure of the water management institutions, but should also include vertical partners in the institution. This implies that water management in a basin should include role players from the individual user to the national regulator, as well as various partners at each level. These stakeholders need to have a voice in water planning and management, with particular attention to securing the participation of women and the poor (Manyatsi and Brown, 2009).

Respondents in the Inkomati survey indicated that RBOs had performed relatively well in their stakeholder participation responsibility. From the perspective of RBOs facilitating horizontal participation of stakeholders in water management in the IRB, respondents in the survey were requested to determine the extent of private sector involvement in RBO operational activities. The South African respondents indicated that private sector involvement is weak in water supply and maintenance; but high in water treatment and water quality monitoring. This could perhaps be attributed to the fact that in many areas of South Africa the role of water service provision, although a local government responsibility, is often supported by a professional service provider from the private sector. These services would be linked to both a water treatment and water quality monitoring function in the basin. In Swaziland, respondents indicated that the private sector is highly involved in all responsibilities of the RBO.

To gauge individual's (vertical) participation in water resource management in the IRB, respondents were asked whether they knew how often catchment meetings were called, whether they attend these meetings and what the level of stakeholders' involvement was in the meetings. Over half of the respondents in South Africa and Swaziland indicated that catchment meetings are called on a quarterly basis. A relatively high percentage of these respondents indicated that they attend these meetings.

\section{Institutional capacity building}

Once the institutional framework for IWRM has been determined, there may be a need to develop and upgrade the skills and understanding of various role players in this institution, including decision-makers, management and professionals in these organisations (GWP, 2004). Capacity building then needs to be initiated for all levels of the institutions, i.e., from the regulator to the water users.

According to Manyatsi and Brown (2009 p. 30), in Swaziland 'the formulation of the revised IWRM Plan is still a work in progress and such progress has been hampered by capacity constraints within water professionals in the country. Much of the technical capacity to collect, collate and develop strategies is limited to a few individuals. Similarly, the human capacity may not be available to introduce economic water accounts and IWRM capacity may also be limited in the country.

At a local management level, respondents in this IRB survey indicated that a number of local water management institutions have been developed. Respondents were asked whether these local institutions have sufficient human resources capacity to implement IWRM. In South Africa, just under two-thirds of the respondents indicated that there was sufficient human resource capacity at the local institution level while only a third of respondents in Swaziland indicated similar confidence in levels of human capacity within these local institutions. Capacity building was not a criterion which was extensively measured in this assessment of the IRB. Since institutionalisation of RBOs is still in its formative stages in South Africa and Swaziland, it is perhaps premature to assess capacity building efforts in these organisations.

\section{IWRM management instruments}

The GWP (2004 p. 21) outlines that management instruments are the 'elements and methods that enable and help decision makers to make rational and informed choices between alternatives'. Experiences and performance of implementation in seven change areas within Pillar 3: Management Instruments in the case study countries in the IRB are evaluated in the following sections:

\section{Demand management}

Demand management involves the balancing of water supply in the basin with the demand for water from the resource, effectively maximising the efficient use of existing water supplies rather than developing new ones (GWP, 2004).

South Africa has introduced and implemented national efforts for water conservation and demand management. The country is serious about demand management of water resources and has, as a result, developed a Water Conservation and Demand Management Strategy for the country (RSA, 2004). RBOs and WSAs have a role to play in managing and reporting water demand data within their jurisdiction.

According to Manyatsi and Brown (2009) water use information in Swaziland is generally lacking. Irrigation water use in the country is monitored through the permitting system; however, the actual volume of water used is poorly monitored and these data are difficult to access. National data on water use, which is the responsibility of DWA, were last captured in 1996. Similarly, data are available for some sectors but not for others.

Respondents in this study of IWRM were asked whether the RBO monitors water use in the basin. The majority of respondents were positive that water use monitoring was being conducted by the RBOs.

\section{Conflict resolution}

Mechanisms for managing conflict are key criteria in IWRM as conflict is endemic in the management of water resources. These mechanisms may include resolution models (GWP, 2004).

In this assessment of IWRM in the IRB, respondents were asked whether there are forums to hear disputes and how often these forum meet. The majority (72\%) of respondents mentioned that there are forums for disputes, $42 \%$ of respondents indicated that forums meet when need arises and 33\% of them indicated that forums meet quarterly. Analysis at the country level shows that the majority of respondents who agreed to dispute forums being in place are from South Africa. The majority of Swaziland respondents indicated that no such forums are in place for dispute resolution.

When respondents were further asked to indicate the types of disputes raised during forum meetings, South Africa's wide range of issues included: water licences; water resource issues (ground vs. surface water); water pricing, re-allocation and compensation; benefits in return for Reserve that goes to Mozambique; sewage system and pollution incidence; accessibility to water resources and unfair allocation; water availability; water quality status; river flow levels, establishment of WUAs; 
signing of Bill Agent agreements by DWA; development of water storage, complaints by communities about sharing of water usage (e.g. the allocated water registration volume per month, not fully utilised and the portion allocated to other users).

The South African respondents were split in their perception of the level of success of RBO in resolving disputes. About $71 \%$ of these respondents indicated a moderate level of success while $25 \%$ indicated no success by the RBO in addressing the disputes.

\section{Regulatory instruments}

Regulations are important in supporting implementation of water policies and legislative imperatives, providing the 'operational guide' (GWP, 2004). The survey further assessed the level of respondents' knowledge of the water use authorisation procedure in the IRB. Analysis of the result indicates that the majority of the respondents were aware of a water authorisation procedure in the basin, with almost all of these respondents indicating that they were familiar with the water use authorisation requirement.

\section{Economic instruments}

Economic tools involve the use of prices, subsidies, and other market-based measures to provide incentives to all water users to use water carefully, efficiently and avoid pollution (GWP, 2004). The two countries have adopted the polluter-pays and user-pays principles. However, the manner in which to implement these principles, particularly the polluter-pays principle, remains unclear and complex. Current systems of user-pays principle implementation by RBOs are in their infancy, with tariff collection currently resting with central government. Similarly, the complex principle of polluter-pays has not been operationalised in South Africa, with central government still developing a strategy of tariffing for this principle.

\section{Information management and exchange}

Like monitoring systems, information management systems are required to support water decision making, evaluation and review of water resources for sustainable water resource development and utilisation (Manyatsi and Brown, 2009). Information management systems for data sharing increase stakeholder access to information stored in public domain data banks and effectively complement more traditional methods of public information (GWP, 2004).

A low percentage of respondents answered this section of the survey. South African respondents indicated that sources of information sharing, other than catchment meetings, included annual reports, newsletters and websites as sources of information in the river basin. The Swaziland respondents did not provide details on information management systems because the process of IWRM is still in the formative stage in this country.

\section{LESSONS LEARNT FROM PILOTING THE IWRM IMPLEMENTATION ASSESSMENT METHOD}

Some of the key lessons learnt in the application of the performance assessment tool were:

- Stakeholder engagement: Stakeholder involvement in the piloting of this IWRM implementation assessment was particularly challenging. Despite following a structured stakeholder engagement protocol and various engagement processes and avenues being attempted, there was low response and poor participation in the study. This problem does not however seem limited to this particular survey - in compiling the Institute of Water and Sanitation Development (IWSD) in Zimbabwe's Assessment of Integrated Water Resources Management Activities in the Southern Africa Region, similar difficulties were experienced (Institute of Water and Sanitation Development, 1997).

- The format of the data collection tools (questionnaires) was relatively long and required a significant amount of time to complete (1-2 hours).

- Some of the questions in the questionnaire required rewording or more clarity as respondents did not answer the question or misinterpreted the intent of the question.

- The format of the data collections tools did not facilitate ease of data capture.

- There were gaps in the questionnaire, particularly in the change areas of IWRM plans, institutional capacity building and resource assessments.

A review of IWRM implementation using the method developed and tested in this study shows that the methodology does provide useful data and information. For example application of the methodology allowed the conclusion to be drawn that the countries had largely created an IWRM enabling environment. This is significant as having the policy and legislative environment in place to facilitate and encourage IWRM is crucial to the sector. However, the method showed that some change areas demonstrated varied levels of success.

The hierarchical approach which was utilised to conduct the IWRM performance assessment was effective in providing a structured manner for analysis and interpretation of the results of the assessment. Review of the hierarchy, however, indicates that a level is missing in the structure, i.e., the level of 'indicator' (Fig. 6). Including a series of indicators for each change area would clearly articulate what measures should be utilised to assess a change area. Similarly, indicators would provide a clear signal of which measures (questions) are required in the performance assessment tools to measure a change area. The assessment tools (questionnaires) should be redesigned accordingly to include a level for assessment indicators.

The current hierarchy does not necessarily capture all of the change areas required to successfully implement IWRM. Orlove and Caton (2010) indicate that IWRM principles address all of the themes they deem necessary to manage water scarcity and degradation, namely, water rights, equity, governance, politics, and knowledge, but that IWRM does not explicitly address the local-level politics of decision making in water-constrained situations. The political landscape in which IWRM is implemented has a demonstrable impact on the success of implementation (Orlove and Caton, 2010; Swatuk, 2005). Similarly the funding landscape in which IWRM-related policy and legislative reform takes place has also been shown to have an impact on the nature of the reform which takes place and thus the implementation of IWRM in a country (Mehta et al., 2014). Similarly, gender considerations and conflict and discourse mechanisms are not addressed in the current hierarchy, particularly capturing conflict and discourse resolution mechanisms between countries, river basins and water users. 


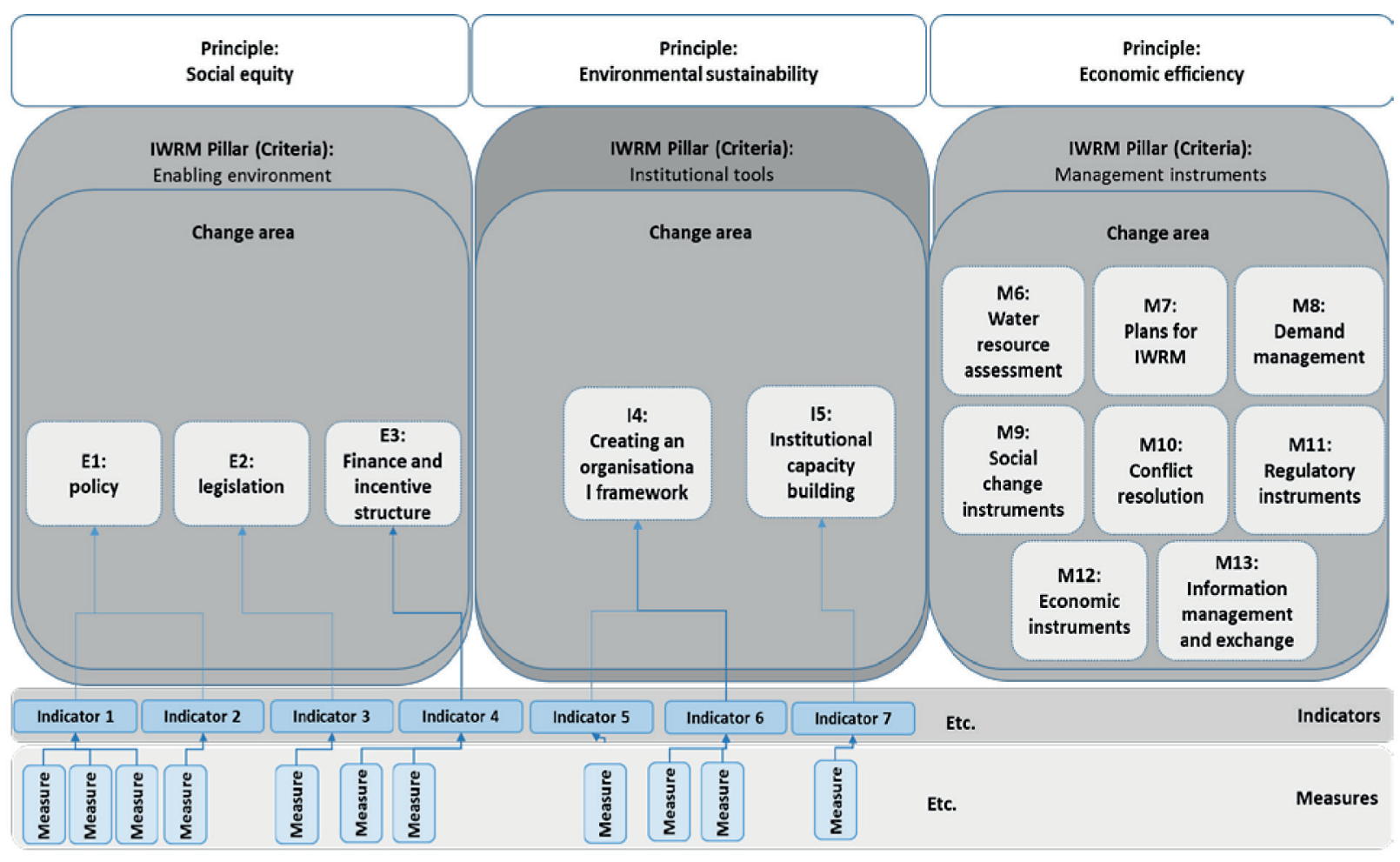

Figure 6

Recommended hierarchical structure for assessment of IWRM implementation

\section{CONCLUSIONS}

It is clear from the results of the piloting of an IWRM assessment tool in the IRB that there are gaps in the tool, particularly related to assessment of the IWRM management instruments. As a result our pilot testing of the tool in the IRB did not provide insights into water resource assessment, IWRM plans, demand management and regulatory instruments in the basin. The results from the pilot also showed that countries should consider a phased approach to assessment of IWRM, as implementation does seem to follow a graduated process of first creating the enabling environment, followed by the formulating and implementing of the institutional framework and then creating and application of IWRM management instruments.

A significant step forward has been achieved with the IWRM enabling environment being largely in place in South Africa and Swaziland. This is a significant development as the policy and legislative environment is the most crucial to guide and regulate the sector in future. Currently, the financial enabling environment is one major weakness as mechanisms to ensure water management institutions (RBOs) become selfsustaining are still being developed or are only partially implemented. Central government is still required to provide the financial resources needed to sustain these institutions in South Africa and Swaziland.

The IWRM institutional framework and roles are also largely in place in the IRB. However, change areas within these criteria demonstrate varied levels of success. Institutional structures, roles and responsibilities have successfully been articulated in policy and legislation in the basin. Implementation of these policy and legislative IWRM imperatives, however, remains a challenge. Stakeholder participation does seem to be one of the successes of the institutional framework in the
Inkomati River Basin. However, greater attention needs to be paid to capacity building in future IWRM endeavours.

The IWRM management instruments are perhaps the least developed change areas of the Inkomati. This is to be expected as management instruments are effectively the implementation tools for IWRM. With the implementation of IWRM still relatively new in the Inkomati River Basin, one would expect that these management instruments will develop as the IWRM process progresses. However, the current conflict resolution mechanisms should be noted, as should the initial regulatory instruments.

\section{ACKNOWLEDGEMENTS}

The article draws on the research project 'Water governance decentralisation in Africa: a framework for reform process and performance analysis' funded by the Water Research Commission. We thank the Water Research Commission for funding and Eiman Karar as the project manager of this research. We also thank other contributors such as the project steering committee members who contributed comments and Ariel Dinar, S Farolfi, and Pegasus for their valuable inputs at earlier stages of this research. We thank all of the stakeholders who participated in the study.

\section{REFERENCES}

CARMO VAZ A and PEREIRA A (2000) The Incomati and Limpopo international river basins: a view from downstream. Water Polic. 299-112.

GLOBAL WATER PARTNERSHIP (GWP) (2000) Integrated water resource management. TAC Background No.4. URL: http://www. gwp.org/gwp/library/Tacno4.pdf (Accessed 15 May 2014).

GLOBAL WATER PARTNERSHIP (GWP) (2004) Catalysing Change: A Handbook for Developing Integrated Water Resources Management (IWRM) and Water Efficiency Strategies. United 
Nations Department of Economic and Social Affairs, Stockholm.

GLOBAL WATER PARTNERSHIP (GWP) and the INTERNATIONAL

NETWORK OF BASIN ORGANIZATIONS (INBO) (2009) A

Handbook for Integrated Water Resources Management in Basins. Elanders, Stockholm.

HASSAN R, MTSWENI A, WILKINSON M, WESTON D, MUTUNDO J, MAGAGULA T, SITHOLE P, FAROLFI S and DINAR A (2014) Water governance decentralization in Africa: A framework for reform process and performance analysis. WRC Report No 1969/1/14. Water Research Commission, Pretoria.

INSTITUTE OF WATER AND SANITATION DEVELOPMENT (IWSD) (1997) Assessment of integrated water resource management activities in the Southern African Region: A preliminary inventory. URL: http://www.africanwater.org/IWRM_Zimbabwe. htm (Accessed 2 February 2015).

ICWE (INTERNATIONAL CONFERENCE ON WATER AND ENVIRONMENT) (1992) Development Issues for the 21st Century. The Dublin Statement and Report of the Conference, Dublin, Ireland, 26-31 January 1992. World Meteorological Organization, Geneva.

MANYATSI AM and BROWN R (2009) IWRM survey and status report: Swaziland. GWP Southern Africa, Swaziland.

MEHTA L, ROSSELLA A, BOLDING A, DENBY K, DERMAN B, HOVE T, MANZUNGU E, MOVIK S, PRABHAKARAN P AND VAN KOPPEN B (2014) The politics of IWRM in Southern Africa. Int. J. Water Resour. Dev. 30 (3) 528-542.

MINISTRY OF NATURAL RESOURCES AND ENERGY, NATIONAL WATER AUTHORITY (2009) National Water Policy, Swaziland Government, Mbabane.

ORLOVE B AND CATON SC (2010) Water sustainability: Anthropological approaches and prospects. Ann. Rev. Anthropol. 39 401-415.

PRINSLOO A (2008) A critical analysis of LRAD sub-programme in Gauteng Province of South Africa, MInstAgrar dissertation, University of Pretoria, Pretoria. URL: http://upetd.up.ac.za/thesis/ available/etd-08112009 (Accessed 15 May 2014).

REPUBLIC OF SOUTH AFRICA (RSA) (1994) Water Supply and Sanitation Policy White Paper. Government Printers, Pretoria.

REPUBLIC OF SOUTH AFRICA (RSA) (1997) White Paper on a National Water Policy for South Africa. Government Printers, Pretoria.

REPUBLIC OF SOUTH AFRICA (RSA) (1998) National Water Act. Act No. 36 of 1998. Government Gazette 19182. Government Printers, Cape Town.
REPUBLIC OF SOUTH AFRICA (RSA) (2004) National Water Resource Strategy. Government Printers, Pretoria.

REPUBLIC OF SOUTH AFRICA (RSA) (2007) Water Services Act. Act No. 30 of 2007. Government Gazette 18522. Government Printers, Cape Town.

REPUBLIC OF SOUTH AFRICA (RSA) (2013) National Water Resource Strategy: Water for an equitable and sustainable future. Government Printers, Pretoria.

SAUNDERS M, LEWIS P and THORNHILL A (2007) Research Methods for Business Students (4th edn). Prentice Hall, London.

SCHREINER B AND HASSAN R (2011) Transforming Water Management in South Africa: Designing and Implementing a New Policy Framework. Springer, London.

SLINGER JH, HILDERS M, JUIZO D (2010) The practice of transboundary decision-making on the Incomati River: Elucidating underlying factors and their implications for institutional design. Ecol. Soc. 15 (1) 1.

SWATUK LA (2005) Political challenges to implementing IWRM in Southern Africa. Phys. Chem. Earth 30 872-880.

SWAZILAND (2003) Water Act, Act No. 7 of 2003. Government Printers, Mbabane, Swaziland. URL: http://www.ielrc.org/content/ e0309.pdf (Accessed December 2013).

UNCED (UNITED NATIONS CONFERENCE ON ENVIRONMENT AND DEVELOPMENT) (1992) The Rio Declaration on Environment and Development (1992). URL: http://www.unesco. org/education/nfsunesco/pdf/RIO_E.pdf (Accessed 15 May 2014).

UNITED NATIONS ENVIRONMENTAL PROGRAM (UNEP) (2012) Status report on the application of integrated approaches to water resources management. United Nations Environment Programme, Nairobi.

VAN DER ZAAG P (2005) Integrated Water Resource Management: Relevant concept or irrelevant buzzword? A capacity building and research agenda for Southern Africa. Phys. Chem. Earth 30 (11-16) 867-871.

VAN DER ZAAG P and CARMO VAZ A (2003) Sharing the Incomati waters: cooperation and competition in the balance. Water Polic. 5 349-368.

ZAIKOWSKI L (2007) Water Profile of Swaziland. In: Cleveland CJ (ed.) Encyclopaedia of Earth. Environmental Information Coalition, National Council for Science \& Environment, Washington DC. URL: http://www.eoearth.org/article/waterpolicyofSwaziland (Accessed 15 May 2014). 